Kredo 4 (2021)
KREDO: Jurnal Ilmiah Bahasa dan Sastra
Terakreditasi Sinta 4 berdasarkan Keputusan
Direktorat Jenderal Penguatan Riset dan
Pengembangan, Kementerian Riset, Teknologi dan
Pendidikan Tinggi Republik Indonesia
Nomor: 23/E/KPT/2019.08 Agustus 2019
https://jurnal.umk.ac.id/index.php/kredo/index

\title{
STUDENTS' LANGUAGE AWARENESS ON LINGUISTICS PROBLEMS DURING NEGOTIATION OF MEANING IN PAIR WORK DISCUSSION
}

\author{
Flora \\ nainggolan.flora@yahoo.com \\ Lampung University, Indonesia
}

\section{Info Artikel \\ Sejarah Artikel \\ Diterima \\ 13 Agustus 2020 \\ Disetujui \\ 8 April 2021 \\ Dipublikasikan \\ 9 April 2021}

\section{Keywords}

Language awareness, linguistics problems, negotiation of meaning, willingness and unwillingness

\section{Kata Kunci}

Kepedulian bahasa, masalah kebahasaan, proses negosiasi makna, keingingan dan ketidak inginan.
$:$

The objectives of this study are :1) to describe linguistics problems produced by the students during the negotiation of meaning in pair work discussion, and 2) to describe the students' language awareness (willingness and unwillingness to correct the linguistics problems). This study applied descriptive quantitative design and the subjects are 3 pairs consisting of high-high $(\mathrm{H}-\mathrm{H})$ learner, high and low (H-L) learner and low- low (L-L) learner. All of them are the fourth semester students of English department of teachers training faculty of Lampung University in academic 2018/2019. Each pair was given a topic (chosing 5 personality traits that a teacher should have). Each pair discussed the topic and during the discussion, all their utterances were recorded, transcribed and were analyzed based on relevant theories. The results show that each pair produced linguistics problems, such as grammatical and vocabulary. Most of the learners, especially H-L and L-L are not aware of linguistics problems because they focus more on the message across. Eventhough some of the pairs are aware of linguistics problems and are willing to correct them, it does not gurantee that the input can be internalized by their pairs since they focus more on meaning during the interaction. Therefore, it is suggested further researchers investigate this phenomena.

\section{Abstrak}

Tujuan penelitian ini adalah untuk: 1) mendiskripsikan masalah kebahasaan pembelajar selama proses negosiasi makna pada diskusi yang dilakukan secara berpasangan, 2) mendeskripsikan kepekaan pembelajar (keinginan utuk memberi koreksi dan ketidak inginan untuk memberi koreksi) terhadap kesalahan kebahasaan yang terjadi selama diskusi. Subyek penelitian kualitatif ini adalah tiga pasang pembelajar yang terdiri atas; 1) pasangan yang sama-sama memiliki kemampuan yang baik, 2) satu pasang yang memiliki kemampuan yang baik dan kurang baik, dan 3) satu pasang yang memiliki pasangan yang kemampuannya sama-sama kurang baik. Mereka adalah mahasiswa FKIP-Universitas Lampung pada tahun akademik 2018/2019. Setiap pasangan diberikan topik yang sama untuk didiskusikan. Semua ujaran selama diskusi, direkam, ditranskripsi, dan dianalisis berdasarkan teori yang relevan. Hasil penelitian menunjukkan bahwa semua pasangan memproduksi kesalahan kebahasaan, seperti tatabahasa dan kosa-kata. Hampir semua pembelajar, tidak terlalu memperhatikan kesalahan kebahasaan karena mereka terfokus pada pesan yang disampaikan. Walaupun ada beberapa koreksi, namun tidak bisa disimpulkan bahwa koreksi itu dipahami oleh yang dikoreksi karena dia lebih terfokus bagaiman agar dia dipahami oleh lawan bicaranya. Oleh karen itu, disarankan adanya penelitian untuk meneliti phenomena ini. 


Kredo 4 (2021)
KREDO: Jurnal Ilmiah Bahasa dan Sastra
Terakreditasi Sinta 4 berdasarkan Keputusan
Direktorat Jenderal Penguatan Riset dan
Pengembangan, Kementerian Riset, Teknologi dan
Pendidikan Tinggi Republik Indonesia
Nomor: 23/E/KPT/2019.08 Agustus 2019
https://jurnal.umk.ac.id/index.php/kredo/index

\section{INTRODUCTION}

Language awareness is needed by foreign language learners because it enables them to notify the mistakes and try to correct them. Restrepo (2006) and Rahmi and Erlinda (2014) stated that if someone has high language awareness, $\mathrm{s} / \mathrm{he}$ will have curiosity. In line with this statement, Bourke (2008) declared that in 1990s, grammar instruction using communicative approach had positive effect on the learners' grammar quality. Having explicit and implicit explanation, the students were able to notify the rules of grammar and consequently, they were able to use the rules appropriately. $\mathrm{He}$ further stated that language awareness is crucial in learning process. In short, the learners tried to find the formula of the sentence (Perez, 2006) and make them aware of the rules (Gavidia, 2012). Prior to this, Tomlinson (2003) stated that language awaresness can be done by motivating the learners to understand the forms and form of the language. In relation to language awareness, there were many studies that have been conducted by the previuos researchers, such as; Piper (2003), Perez (2006), Gavidia (2012), Yang (2013), Rahmi \& Erlinda (2014), Oel (2016), and Saenz (2016). The result of their findings show that language awerenes gave benefits to the learners' language quality.
Littlewood (1981) stated that in learning a new language, the teacher should give enough chance to practice the language. Without having enough practice, he believed that only a little learning of a new langauage can take place. This idea inspired the experts, such as Pica $(1985,1994)$ to promote negotiation of meaning. The teachers are suggested to prepare the task that make the learners negotiate the meaning during the interaction. Therefore there are bmany researchers who have conducted the research on negotiation of meaning, for examples; Pica (1985,1994; Yufrizal (2007); Yazigi and Seedhouse (2005); Luciana (2005); Arslanyilmaz dan Pedersen, (2010); Bower dan Kawaguchi (2011); Castrillo, Monje, and Bárcena E (2011); Farangis, 2013). They claimed that the learners use negotiation of meaning such as comprehension checks, clarification request and comprehension checks. The learners tried to understand each other during the interaction and consequently it can be assumed that the primary function of negotiataion of meaning is to get the message across. In other words, they are not aware too much on linguistic problem because the learners sometimes use they own language if they have problems in expressing their ideas in the target language, English (Nurazizah and Sutopo, 2018).

\section{Language awareness can also be} grouped into language technique. 


Kredo 4 (2021)
KREDO: Jurnal Ilmiah Bahasa dan Sastra
Terakreditasi Sinta 4 berdasarkan Keputusan
Direktorat Jenderal Penguatan Riset dan
Pengembangan, Kementerian Riset, Teknologi dan
Pendidikan Tinggi Republik Indonesia
Nomor: 23/E/KPT/2019.08 Agustus 2019
https://jurnal.umk.ac.id/index.php/kredo/index

This is based constructivist approaches (Gavidia, 2012). Constructivist believed that knowledge is built step by step by asking students to observe the phenomena, to make hyphotesis and to have conclusion. Based on this idea, it can be concluded that language awareness occurred when the learners use cognitive strategies such as noticing, hypothesis testing, problem solving, and restructuring. However, Syalberg (2007: 290) stated that in teaching grammar, explicit explanation is more effective than implicit explanation. This idea might be difficult to do during group or pair work discussion because it may disturb the learners to express their ideas. This is one of the factors that make the learners are not willing to correct or solve the linguistics problems occured during the interaction.

Refering to the elaboration above, it is needed to explore deeper about language awareness during the negotiation of meaning in pair work discussion. In addition, Bourke (2008), Luciana (2005), and Hartono (2017) suggested to group the learners by considering their ability so that the interaction can run well and consequently the input for language quality is better. Dealing with this statement, in this present study, the pair is paired based on the students' English ability. In addition, willingness to correct by the listener (interlocutor) is $461 \mid$ Jurnal Kredo

Vol. 4 No. 22021 also needed. Swain and Lapkin (1995) stated that the learner also can get input from his own output. For example, if $\mathrm{s} /$ he makes a mistake, and the listener gives correction, automatically he can get input from his own output. Therefore, the objectives of this study are :1) to describe the linguistics problems ( the mistake of grammar and vocabulary) produced by the students during the negotiation of meaning in pair work discussion, and 2) to describe the students' language awareness (willingness and unwillingness to correct the mistakes) during the negotiation of meaning in pair wok discussion.

\section{LITERATURE REVIEW}

In this part, it will be elaborated the theories related to negotiation of meaning, and language awareness.

\section{A. Negotiation of meaning}

Negotiation of meaning occurred during the interaction between speakers and listeners. The speakers involved in the interaction make negotiation of meaning so that they can understand each other. Pica $(1985,1994)$ stated that usually consists of; 1 . trigger 2. Signal, and 3. Response.

1. Trigger (the utterance which causes misunderstanding or Utterance followed by signals of total or partial lack of understanding. 


Kredo 4 (2021)
KREDO: Jurnal Ilmiah Bahasa dan Sastra
Terakreditasi Sinta 4 berdasarkan Keputusan
Direktorat Jenderal Penguatan Riset dan
Pengembangan, Kementerian Riset, Teknologi dan
Pendidikan Tinggi Republik Indonesia
Nomor: 23/E/KPT/2019.08 Agustus 2019
https://jurnal.umk.ac.id/index.php/kredo/index

\section{Signal}

The same thing as trigger. For this, the people involved in the interaction usually make some efforts, suh as;

A) Confirmation check. This is usually done by having;

1) Request for confirmation through repetition.

A: I choose Dr. Lee.

B: Dr. Lee?

2) Request for confirmation through modification or correction.
A: A teacher should patient
B: should be patient.

3) Request for confirmation through completion or elaboration
A: Humorous teacher can make students
B: rilex.

A: yes, rilex.

B) Clarification Request

It is usually done by the listener when s/he does not understand what is being expressed by the speaker using some expressions, such as; Can you repeat?, Sorry?, I do not understand, etc.

\section{Response.}

Response is the reaction of the speaker to the listener's signal.

1) Self-repetition response. This is uttered by a speaker as the reaction to the trigger.
A: There is no more sits left.
B: Not
A : no more...not

2) Other repetition response. The speaker repeats the signal from the listener, as the follolwing example:

A: A teacher should be objective in giving the...

B: the score

A: Yes, the score.

3) Self-modification response. The speaker modifies the trigger, as the following example:

A: There isn't to no more students in the room.

B: Sorry?

A: There is no more students in the class.

4) Other modification response. The speaker modifies the response based on the signal given by the listener, as the following example:

A: If the teacher...aaa...not humorous...the students will be boring.

B: You mean..students will be bored.

A: Iya...ya...students will be bored.

Dealing with the ealaboration above, it can be concluded that negotiation of meaning is the effors of the students to understand each other. Many researches, such as Pica (1985, 1994); Yufrizal (2007); Yazigi and Seedhouse (2005); Luciana (2005); Arslanyilmaz and Pedersen (2010); Bower dan Kawaguchi (2011); Castrillo, Monje, and Bárcena (2011); Farangis (2013) believe that negotiation of meaning have some benefits for language learners. However, the 


Kredo 4 (2021)
KREDO: Jurnal Ilmiah Bahasa dan Sastra
Terakreditasi Sinta 4 berdasarkan Keputusan
Direktorat Jenderal Penguatan Riset dan
Pengembangan, Kementerian Riset, Teknologi dan
Pendidikan Tinggi Republik Indonesia
Nomor: 23/E/KPT/2019.08 Agustus 2019
https://jurnal.umk.ac.id/index.php/kredo/index

primary function of negotiation of meaning is to get the masage across because sometimes they use their own language (Baharun and Othman, 2018; Nurazizah, at al, 2018). In other words, they are not aware too much on language accuracy. Refering to this statement, it can be assumed that the learner can not develop his language quality.

\section{B. Language Awareness}

Language awareness is looked as linguistic problem-solving (Carter, 2003; Bourke, 2008). Similar to this idea, Tomlison (2003:252) stated that language awareness is a conscious attention of the learner to discover the pattern of a sentence. Language awareness is similar to the concept of consciousness proposed by Rutherford (1987). In this case, the learners use cognitive strategies such as noticing, hypothesis testing, problem solving, and restructuring. It means, the learners must have prior knowledge to the problem appeared during the interaction. For example, if someone makes ungrammatical sentence and his listener (interlocutor) can correct the mistake, it means he is in the position of solving the problem. Language awareness is done by the learner himself not by other and it helps the learner in investigating something, for example the rules of a certain sentence. In short, language awareness occured only if the learners have prior knowledge.

Language awareness can also be grouped into language technique. This is based constructivist approaches (Gavidia, 2012). Constructivist believed that knowledge is built step by step by asking students to observe the phenomena, to make hyphotesis and to have conclusion. Based on this idea, it can be concluded that language awareness occurred when the learners use cognitive strategies such as noticing, hypothesis testing, problem solving, and restructuring. However, Syalberg (2007: 290) stated that in teaching grammar, explicit explanation is more effective than implicit explanation. This idea might be difficult to do during group or pair work discussion because it may disturb the learners to express their ideas. This is one of the factors that make the learners are not willing to correct or solve the linguistics problems occured during the interaction.

Refering to the elaboration of negotiation of meaning and language awareness above, it can be concluded that in learning a new language, the teacher should provide the task that makes the learners negotiate the meaning. By having this, they have sufficient time to practice the language as suggested by Littlewood (1981). In addition, language awareness is also needed during the learning process so 


Kredo 4 (2021)
KREDO: Jurnal Ilmiah Bahasa dan Sastra
Terakreditasi Sinta 4 berdasarkan Keputusan
Direktorat Jenderal Penguatan Riset dan
Pengembangan, Kementerian Riset, Teknologi dan
Pendidikan Tinggi Republik Indonesia
Nomor: 23/E/KPT/2019.08 Agustus 2019
https://jurnal.umk.ac.id/index.php/kredo/index

that the quality of language learners can be developed.

\section{METHODOLOGY}

\section{Subject of the research}

The subject of this research was three pairs. The first pair consists of 2 students who are considered good in English ability (high-high learner), the second one is high and low learner and the last is low and low learner. In other words, they were taken purposively. They were the fourth semester students of English department of teachers training faculty of Teachers traing faculty of Lampung University in academic 2018/2019. They were taken purposively. It was done based on Bourke (2008), Luciana (2005), and Hartono (2017) suggestion that in grouping students, it will be better to consider the their level of language ability.

\section{Research Instruments}

Each pair was given a topic to be discussed. They were also instructed to help each other whenever they have problem in expressing their ideas in English. In addition, they were also instructed to give correction whenever they notify the linguistic problem. All their utterances were recorded using their mobile phones.

Data Collection Procedure and Data Analysis

The data were collected by recording the students' utterances during the discusssion. The data then were anayzed as follows:

a. All the utterances were transcribed and counted the number of $\mathrm{C}$-units produced by each learner.

b. Lingusitic problems (grammar and vocabulary mistakes ) produced by each learner were counted.

c. Language awareness (willing to correct and unwilling to correct ) by each learner was counted.

\section{RESULT AND DISCUSSION OF THE RESEACRH}

\section{Results of the Research}

The result of this study is reported based on the research questions elaborated on the background.

RQ 1. How is the mistake of grammar and vocabulary produced by the students during the negotiation of meaning in pair wok discussion?

Table 1. Grammar and vocabulary mistake produced by the students during the negotiation of meaning in pair work discussion.

\begin{tabular}{cccc}
\hline Pair & C-unit & Grammar & Vocabulary \\
\hline H-H & 122 & & \\
H1 & 62 & $5(8 \%)$ & 1 \\
H2 & 60 & $2(3 \%)$ & 0 \\
H-L & 131 & & \\
H & 79 & $5(6 \%)$ & 0 \\
L & 52 & $27(51 \%)$ & 17 \\
L-L & 150 & & \\
L1 & 82 & $42(51 \%)$ & 52 \\
L2 & 68 & $34(50 \%)$ & 44 \\
\hline
\end{tabular}




Kredo 4 (2021)
KREDO: Jurnal Ilmiah Bahasa dan Sastra
Terakreditasi Sinta 4 berdasarkan Keputusan
Direktorat Jenderal Penguatan Riset dan
Pengembangan, Kementerian Riset, Teknologi dan
Pendidikan Tinggi Republik Indonesia
Nomor: 23/E/KPT/2019.08 Agustus 2019
https://jurnal.umk.ac.id/index.php/kredo/index

Chart 1. Grammar and vocabulary mistake produced by the students during the negotiation of meaning in pair work discussion.

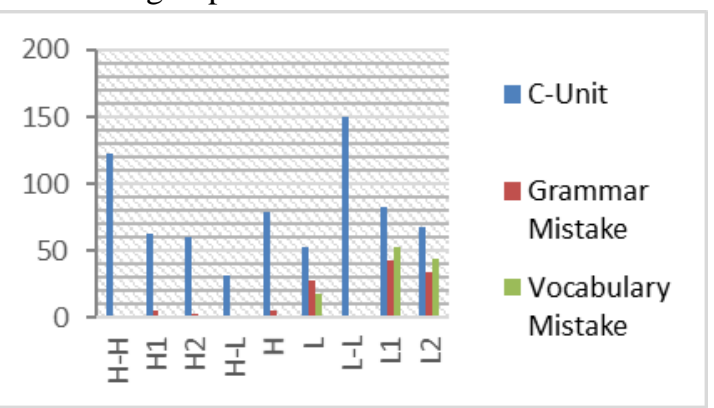

\section{Grammar mistake}

In $\mathrm{H}-\mathrm{H}$ pair, $\mathrm{H} 1$-learner made $5 \mathrm{C}$ units $(8 \%)$ ungrammatically while $\mathrm{H} 2$ learner made $2(3 \%)$. The second pair (H-L). H-learner produced 5 (6\% and Llearner 27 (51\%) ungrammatical C-Unit. The last pair (L-L) produced ungrammatical C-unit $42(51 \%)$ and 34 (50\%), respectively.

\section{Vocabulary Mistake}

Vocabulary mistakes in this study are those the students do not know the meaning of English words or they way how to say Indonesian words in English. In $\mathrm{H}-\mathrm{H}$ pair, H1-learner made only 1 vocabulary mistake while H2-learner did not make any mistake. The second pair is $\mathrm{H}-\mathrm{L}$ pair. H-learner did not make any mistake, while L-learner produced 17 vocabulary mistakes. The last pair (L-L) made 52 vocabulary mistakes and 44, respectively.
RQ 2. How is the students' language awareness during the negotiation of meaning in pair wok discussion?

Table 2. Language Awareness during the negotiation of meaning in pair wok discussion

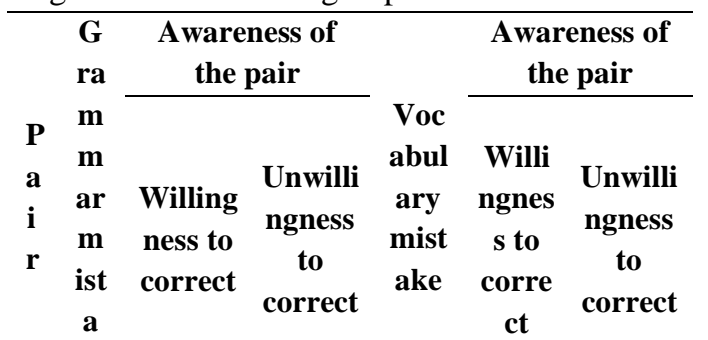
ke

\begin{tabular}{|c|c|c|c|c|c|c|}
\hline \multicolumn{7}{|c|}{ H-H pair } \\
\hline $\begin{array}{c}\mathrm{H} \\
1\end{array}$ & $\begin{array}{c}5 \\
(8 \\
\%)\end{array}$ & $2(40 \%)$ & $\begin{array}{c}3 \\
(60 \%)\end{array}$ & 1 & 0 & 0 \\
\hline $\begin{array}{l}\mathrm{H} \\
2\end{array}$ & $\begin{array}{l}2 \\
(3 \\
\%)\end{array}$ & $0 \%$ & $0 \%$ & 0 & 0 & 0 \\
\hline \multicolumn{7}{|c|}{ H-L pair } \\
\hline $\mathrm{H}$ & $\begin{array}{l}5 \\
(6 \\
\%)\end{array}$ & $0 \%$ & $0 \%$ & 0 & 0 & 0 \\
\hline $\mathrm{L}$ & $\begin{array}{l}27 \\
(51 \\
\%)\end{array}$ & $3(11 \%)$ & $\begin{array}{c}24 \\
(89 \%)\end{array}$ & 17 & 7 & 10 \\
\hline \multicolumn{7}{|c|}{ L-L pair } \\
\hline $\begin{array}{l}\mathrm{L} \\
1\end{array}$ & $\begin{array}{l}42 \\
(51 \\
\%)\end{array}$ & $1(2 \%)$ & $\begin{array}{c}41 \\
(98 \%)\end{array}$ & 52 & 3 & 49 \\
\hline $\begin{array}{l}\mathrm{L} \\
2\end{array}$ & $\begin{array}{c}34 \\
(50 \\
\%)\end{array}$ & $2(6 \%)$ & 32 & 44 & 4 & 40 \\
\hline
\end{tabular}




Kredo 4 (2021)
KREDO: Jurnal Ilmiah Bahasa dan Sastra
Terakreditasi Sinta 4 berdasarkan Keputusan
Direktorat Jenderal Penguatan Riset dan
Pengembangan, Kementerian Riset, Teknologi dan
Pendidikan Tinggi Republik Indonesia
Nomor: 23/E/KPT/2019.08 Agustus 2019
https://jurnal.umk.ac.id/index.php/kredo/index

Chart 2. Language Awareness during the negotiation of meaning in pair wok discussion

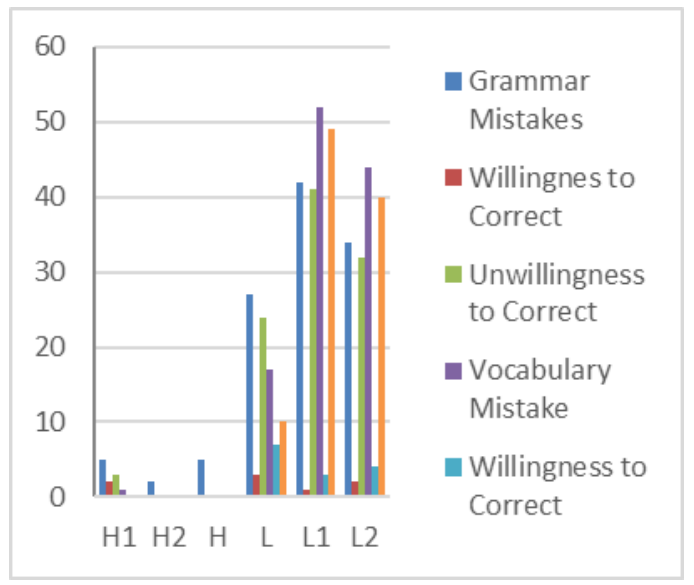

Language Awareness on Grammar Mistakes : Willingness to correct.

H1-H2 pair

The first pair, H2-learner was aware of the mistakes but she was only willing to correct $2(40 \%)$ while the other $3(60 \%)$ mistakes, she was not willing to correct them.

In $\mathrm{H}-\mathrm{H}$ pair, H1-learner made $5 \mathrm{C}$-units $(8 \%)$ ungrammatically while $\mathrm{H} 2$-learner made $2(3 \%)$.

\section{Extract (1)}

H1: Hmm... yes I think so because, hmm... when a teacher is a charming aaa..the

students will not aaa... boring in the class.

H2: will not be bored

H1: Mmm. will not be bored in the class.
H-L pair

While the second pair $(\mathrm{H}-$

L), H-learner made 5 (6\%) ungrammatical sentences, but her interlocutor (L-learner) did not give any correction. While her pair (L-learner) made $27 \quad(51 \%)$ ungrammatical sentences but only 3 (11\%) were corrected. For example;

$$
\text { Extract (2) }
$$

L: Oh..iya, in my opinion,hmm ....a teacher should have ee e.... should should .. honest... honest.

$H$ : should be honest.

L: should be honest ...because, ee.... in my opinion, if $e$ if the teacher not honest to the students, ee.... sometimes the students eeee.... apa...kesal

\section{L-L pair}

The last pair (L-L pair), made the highest ungrammatical sentences. L1learner made $42(51 \%)$ ungrammatical sentences but only1 (2\%) were corrected by L2-learner. L2-learner made 34 $(50 \%)$ ungrammatical sentences but only2 (6\%) were corrected by L1learner. For example:

\section{Extract (3)}

L1: Because aaa... as a teacher kalau tidak punya ... apa sih? If she is not have..not have knowledge?

L2: She does not have knowledge 


Kredo 4 (2021)
KREDO: Jurnal Ilmiah Bahasa dan Sastra
Terakreditasi Sinta 4 berdasarkan Keputusan
Direktorat Jenderal Penguatan Riset dan
Pengembangan, Kementerian Riset, Teknologi dan
Pendidikan Tinggi Republik Indonesia
Nomor: 23/E/KPT/2019.08 Agustus 2019
https://jurnal.umk.ac.id/index.php/kredo/index

\section{Extract (4)}

L2: The teacher ..... as a teacher aaa.... how about to say ... aaa .....they should be.have aaa....should be have knowledge.

L1: should have knowledge.

\section{A. Awareness on Grammar Mistake : Unwillingness to correct}

H1-H2 pair

As it was mentioned earlier, $\mathrm{H} 1$-learner made5 (8\%) and $3(60 \%)$ mistakes, her pair $(\mathrm{H} 2)$ was not willing to correct them.

\section{Extract (5)}

H2: So the learning process will runs well

H1: Yeah. Run well

H2: Sorry ..run not runs.

While H2-learner made $2(3 \%)$ grammar mistakes but none is corrected by her pair (H1), as th following extract.

\section{Extract (6)}

H2: I think aaa it's better if the teachers is charming

H1: Am ... why do you say that?

H-L pair

The second pair (H-L). H-learner produced 5 (6\% but none is corrected by L-learner, for example;
H: It will difficult for them in learning

L: Yes

While L-learner made 27 (51\%) mistakes but only her pair (L-learner) produced 27 $(51 \%)$ but $24(89 \%)$ mistakes were not corrected, as the example at the following extract.

\section{Extract (8)}

$H$ : Because if we learn, but the situation is, you know, ... everyone is afraid with the teacher

L: Iya.

The last pair (L-L)

L1 made $42(51 \%)$ but $41(98 \%)$ were not corrected by her pair (L2)

\section{Extract (8)}

L1: Iya, pokoknya kalau dia itu ... the teacher good in..in way of teaching...gitu. L2: ok.

L1: Hmmm...for example..example..she...she can...can to teach....students.

L2: $O k$.

While L2-learner made $34(50 \%)$ but most of the mistakes 2 (94\%) were not corrected, for example:

\section{Extract (9)}

L2: She have inner ... inner what? I don't know.

\section{Extract (7)}




Kredo 4 (2021)
KREDO: Jurnal Ilmiah Bahasa dan Sastra
Terakreditasi Sinta 4 berdasarkan Keputusan
Direktorat Jenderal Penguatan Riset dan
Pengembangan, Kementerian Riset, Teknologi dan
Pendidikan Tinggi Republik Indonesia
Nomor: 23/E/KPT/2019.08 Agustus 2019
https://jurnal.umk.ac.id/index.php/kredo/index

L1: Kayak inner beauty dari dalam udah punya...gitu.

C. Awareness on Vocabulary Mistake: Willingness to correct

Vocabulary mistakes in this study are those the students do not know the meaning of English words or Indonesian words in English.

H1-H2 pair

H1-learner made only 1 vocabulary while H2-learner did not make any mistakes.

\section{Extract (10)}

H1: Monica: aaaa... aaaaa... but actually $I$ can not ...I... I don't understand what generous is. So what is actually generous?

H2: You can say in Indonesian dermawan

\section{H-L pair}

$\mathrm{H}$-learner did not make any mistakes on vocabulary, but her pair $(\mathrm{H})$ made 17. However, H-learner was only willing to correct 7 vocabulary mistakes, as the following extract;

\section{Extract (11)}

L: If she or he not patient in..menghadapi, apa ya?

H: facing

H: oh ... iya, in facing students.

L-L pair
Both of the learners, used code switching during the discussion, as the result, vocabulary mistakes in this pair is the highest. L-1earner made 52 and her pair (L2) only corrected 3.

\section{Extract (12)}

L1: Dia kan nggak punya ...not have..have pengetahuan?

L2: Knowledge

L1: Yes, Knowledge. bagaimana dia untuk ... mengajar....

While L2-learner produced 44 but only 4 mistakes were corrected by L1.

$$
\text { Extract (13) }
$$

L2: Oh, I think is... hmmm.... skill maybe or aaa.... they have ...have...kemampuan. What is kemampuan?

L1: ability.

L2: Iya, ability to teach students.

D. Awareness on Vocabulary Mistake: Unwillingness to correct

H1-H2 pair.

As it was stated earlier, this pair only made 1 mistake (by H1) and it was corrected by her pair (H2).

H-L pair.

L-learner made vocabulary mistake but her pair $(H)$ was not willing to correct 10 mistakes, for example: 


Kredo 4 (2021)
KREDO: Jurnal Ilmiah Bahasa dan Sastra
Terakreditasi Sinta 4 berdasarkan Keputusan
Direktorat Jenderal Penguatan Riset dan
Pengembangan, Kementerian Riset, Teknologi dan
Pendidikan Tinggi Republik Indonesia
Nomor: 23/E/KPT/2019.08 Agustus 2019
https://jurnal.umk.ac.id/index.php/kredo/index

\section{Extract (14)}

L: Oh,,iya, may ee... apa menuntut, menuntut gurunya gitu.. biar hmm.. kok gini si... ee dikiranya nanti.

H: Ok...ok... Then what is the next?

\section{L1-L2 pair.}

This pair made al ot of vocabulary mistakes. LI made 52 but most of them (49) mistakes were not corrected. For example;

Extract (15)

L1: Like...like a pesona sebagai seorang guru maybe.

L2: Yes, I am agree.

The same thing also happened to L2learner. Although she made many mistakes (44) but her pair only corrected 4 mistakes. One of the example is as the following;

\section{Extract (16)}

L2: Yes, so I think is ... emmm..... they are should be aaa..... studying about everything that we ... not we.... that they want to teach with the students. So, how to say about 'so, mereka tidak puas diri gitu dengan apa yang telah ada di dalam diri mereka jadi mereka harus terus belajar, karena sejatinya guru itu adalah seorang pembelajar. How about you?

L1: I think aaa..... it's important to aaa studious aaa.... karena ...

\section{E. DISCUSSION}

H1-learner at the first pair $(\mathrm{H}-\mathrm{H})$ made 2 mistakes (3\%) while his pair (H2) did not make any mistakes. H2learner seemed very careful before expresssing her idea. In addition, she has good ability in grammar. It can be seen from the transcript of their utterances during their discussion. For example, H2learner in $\mathrm{H}-\mathrm{H}$ pair, actually made ungrammatical sentance, but spontaneously she repaired her sentence. For example, "The teacher should patient....should be patient". The same thing also to the H-learner at the second pair $(\mathrm{H}-\mathrm{L})$. In this case negotiation of meaning in form of self-correction happens (Pica, 1985). The learners, especially H-learners make mistakes because they spoke spontaneously and focused on the mesage. However, to make this statement more valid, it needs to conduct an interview dealing with this phenomena.

Based on the result, it can be seen that not all mistakes were corrected by the interlocutor. For example, H2learner was only willing to correct 2 (40\%) mistakes. She was not willing to correct the mistakes because she focused more on meaning. His pair (H2) did the same thing. They focused more on the mesage and talked spontaneously. This finding supports Jones' (2007) statement that when the learners discussed the task among 


Kredo 4 (2021)
KREDO: Jurnal Ilmiah Bahasa dan Sastra
Terakreditasi Sinta 4 berdasarkan Keputusan
Direktorat Jenderal Penguatan Riset dan
Pengembangan, Kementerian Riset, Teknologi dan
Pendidikan Tinggi Republik Indonesia
Nomor: 23/E/KPT/2019.08 Agustus 2019
https://jurnal.umk.ac.id/index.php/kredo/index

themselves, they talked more, and felt free to express the ideas.In short, they were not too much aware of linguistics problems. It can be concluded that the learners have sufficient time to use the language as Littlewood (1981) suggested. But since they are not aware of the mistakes, it will not give any benefits for the learner's language quality development. Eventhough Farangis (2013) declared that negotiation of meaning have some benefits for language learners but if the learners are not aware of the mistakes, it will not give any benefits for the learner's language quality development. In short, this finding supports Foster, at al (2005) who stated that negotiation of meaning is not good for second language acqusition. To support this statement, Nurazizah,at al (2018) stated that during the interaction, the learners of Malay used code-mixing, that is using their own language if they have problems in exprssing their ideas in the target language.

Restrepo (2006) stated that language awareness helps the students to notify the mistakes and try to revise them. This statement might be true if the learning process provides the learners with the strategy to make them aware of the mistakes. In addition, learners' prior knowledge also has the role for solving the problem.
Vocabulary.

The first pair $(\mathrm{H}-\mathrm{H})$, only $\mathrm{H} 2-$ learner made vocabulary mistake, that is 1 and $\mathrm{H}-2$ was aware of it because L-1 asked for help. H1-learner did negotiation of meaning in form of clarification request (Pica, 1985, 1994). Misalnya; What is the meaning of generous?. Based on students utterances on the transcript, H2-learner gave help by translating it into Indonesian language, that is dermawan. The same thing also happened to $H-L$ pair. H-learner in this pair gave help only if the L-learner asked for help. For example;

$Y$ : Apa ya ..... polite, what is polite?

N: Polite is.. sopan.

It seems the learners tried to use the vocabulary they have already possesed. In other words, they tried to avoid the vocabulary they do not know. Most of utterances produced by Llearners consists of code-mixing or codeswitching, for example :" I agree with you, eee... if the.... if a teacher humurous, mmm.... it can make the students ee..... tertarik in learning". This in line with Nurazizah, at al, (2018) who stated that Malay learners used their own lnguage whenever they have problems in expressing their ideas in the target language, English.

Based on this phenomena, the teacher should remind the learners to ask for help during the interaction, especially for vocabulary. For grammar, it is quite 


Kredo 4 (2021)
KREDO: Jurnal Ilmiah Bahasa dan Sastra
Terakreditasi Sinta 4 berdasarkan Keputusan
Direktorat Jenderal Penguatan Riset dan
Pengembangan, Kementerian Riset, Teknologi dan
Pendidikan Tinggi Republik Indonesia
Nomor: 23/E/KPT/2019.08 Agustus 2019
https://jurnal.umk.ac.id/index.php/kredo/index

difficult to make the learners aware and to insist them to give correction with the reasons that in communicative activity, sometimes, ungrammatical sentences sometimes can be understood. For example on Extract (7)

$H$ : It will difficult for them in learning

L: Yes

To make the students aware and to ask them to give help or correction, specific task on grammar, might be appropriate for language awareness. The ungrammatical sentences produced by the students could be given as the topic for the discussion. By doing so, the students have chance to notify ungrammatical sentences, and to try to solve the problem (Bourke, 2008). In addition, this task might make the students more aware of the mistakes and they can share ideas to solve the problem since the topic being discussed (ungrammatical sentences) were produced by themselves. This idea was inspired by Swain and Lapkin (1995) who stated that the learners also can get input from their own output as far as the interlocutors give correction.

\section{F. CONCLUSION}

Negotiation of meaning during the interaction is good for language quality development as far as the learners are aware of linguistics problems. In this study, the data of students' utterances are approximately supported Foster, at al (2005) idea that negotiation of meaning is not good for acquisition since most of the learners are not aware of linguistics problems but they focus more on the message across. Eventhough some of the pairs are aware of the mistakes and are willing to correct them, it does not gurantee that the input can be internalized by their pairs since they focus more on mening during the interaction. Therefore, it is suggested further researchers investigate this phenomena. In addition, in order to arise students' language awareness, focused task (linguistics problems produced by the learners) is an alternative way to make the students notify, hypothesize and make conclusion to the rules. By doing so, their language quality will be much better.

\section{REFERENCES}

Arslanyilmaz and Pedersen. 2010. Enhancing Negotiation of Meaning Through Task Familiarity Using Subtitled Videos in an Online TBLL Environment. TOJET: The Turkish Online Journal of Educational Technology - April 2010, volume 9 Issue 2: 64-77 


Kredo 4 (2021)
KREDO: Jurnal Ilmiah Bahasa dan Sastra
Terakreditasi Sinta 4 berdasarkan Keputusan
Direktorat Jenderal Penguatan Riset dan
Pengembangan, Kementerian Riset, Teknologi dan
Pendidikan Tinggi Republik Indonesia
Nomor: 23/E/KPT/2019.08 Agustus 2019
https://jurnal.umk.ac.id/index.php/kredo/index

Baharun, H., Harun, H, and Othman, J. 2018. Analysis of Negotiation Episodes in Foreign Language Learner Interactions. GEMA Online Journal of Language Studies. Volume 18 (2), May 2018 http://doi.org/10.17576/gema-2018-1802-14

Bourke, J. 2008. A Rough Guide to Language Awareness. Teaching Forum, 1: 12-21.

Bower, Jack ands Kawaguchi, Satomi. 2011. Negotiation of Meaning and Corrective Feedback in Japanese/English e Tandem. Language Learning \& Technology, February 2011, Volume 15, Number 1: 41-57.

Carter, R. A. 2003. Key Concepts in ELT: Language Awareness. ELT Journal 57(1), 6465.

Castrillo, M, D, Monje, E M, and Bárcena E. 2011. New Forms of Negotiating Meaning on The Move: The use of Mobile-based Chatting for Foreign Language Distance Learning. IADIS International Journal on WWW/Internet. Vol. 12, No. 2, pp. 5167.

Farangis, Saeedi. 2013. The Effect of Negotiation in Second Language Acquisition. Educational Journal. Published online, November 10, 2013. http://www.sciencepublishinggroup.com/j/edu) doi:10.11648/j.edu.20130206.15

Foster, Pauline, Ohta and Amy, S. 2005. Negotiation for Meaning and Peer Assistance in Second Language Classrooms. Applied linguistics, 26(3), 402-430.

Gavidia, J.L. 2012. Using Language Awareness Technique to Improve the Level of Achievement in the English Skills of the Students Taking a Aaster's Program in Education in a Private University. Thesis: Universidad De Piura, Lima, Peru.

Hartono, R. 2017. A Critical Review of Research on Negotiation of Meaning in Second Language Learning. Jurnal Bahasa dan Sastra, Volume 6 No. 1 Juli 2017. ISSN online: $2477-3794$.

Jones, L. 2007. The Student-Centered Approach. New York: Cambrigde University Press. 


Kredo 4 (2021)
KREDO: Jurnal Ilmiah Bahasa dan Sastra
Terakreditasi Sinta 4 berdasarkan Keputusan
Direktorat Jenderal Penguatan Riset dan
Pengembangan, Kementerian Riset, Teknologi dan
Pendidikan Tinggi Republik Indonesia
Nomor: 23/E/KPT/2019.08 Agustus 2019
https://jurnal.umk.ac.id/index.php/kredo/index

Littlewood, W. 1981. Communicative Language Teaching. Cambridge: Cambridge University Press.

Luciana, Thio. 2005. Negotiation of Meaning in Communicative Tasks. Indonesian Journal of English Language Teaching. Volume 1/Number 1.:46-63.

Nurazizah, N., Agustien, H., \& Sutopo, D. 2018. Learners's ability to Negotiate Meaning in Interactional Conversation. ELT Forum: Journal of English Language Teaching,7(1): 15-23.

Oel, M.V. 2016. Language Awareness in Efl Grammar Assignments. Thesis: Nederland B.V.

Perez, A. I. R. 2006. Implementing a Language Awareness Approach to Grammat Through Topics. Thesis (Unpublished). Institucion Educativa Comercial Antonio Roldan Betancur (IECARB), Bello.

Pica, T and Doughty. 1985. Interactional Modification in Negotiation of Meaning: A Comparison of Lock Step System and Group Work Interaction. In Susan M. Gass and Carolyn G. Madden (eds). Input in Second Language Acquisition. New York: Newbury House Publishers.

Pica, Teresa. 1994. Review article. Research on Negotiation: What Does it Reveal About Second Language Learning: Conditions, Processes, and Outcomes?. Language Learning 44:3, September 1994: 493-527.

Piper, D. 2003. Language Awareness in Nova Scotia Schools: An Exploratory Study. Brock Education, Acadia University, Vol.13. No.1:61-71

Rahmi, M. \& Erlinda, R. 2014. Developing Students' Language Awareness Through Discovery Learning in English Language Teaching. SELT.

Restrepo, A. I. 2006. Implementing a Language Awareness Approach to Grammar Through Topics. Medellin: Universidad de Antioquia.

Rutherford, W., E. 1987. The Meaning of Grammatical Consciousness-Raising. World Englishes, Vol. 6, No. 3: 209-216.

473| Jurnal Kredo

Vol. 4 No. 22021 


Kredo 4 (2021)
KREDO: Jurnal Ilmiah Bahasa dan Sastra
Terakreditasi Sinta 4 berdasarkan Keputusan
Direktorat Jenderal Penguatan Riset dan
Pengembangan, Kementerian Riset, Teknologi dan
Pendidikan Tinggi Republik Indonesia
Nomor: 23/E/KPT/2019.08 Agustus 2019
https://jurnal.umk.ac.id/index.php/kredo/index

Saenz, D.M.C. 2016. Exploring Language Awareness in EFL Second Grades. Thesis: Universidad Distrital Fransisco Jose De Caldas.

Svalberg, A. M-L. 2007. Language Awareness and Language Learning. Language Teaching 40(4): 287-308.

Swain, M. and S. Lapkin. 1995. Problems in Output and The Cognitive Processe They Generate: A Step Towards Second Language Learning.' Applied Linguistics 16:371-391.

Tomlison, B. 2003. Developing Materials in Language Teaching. London: Continuum Press.

Yang, Y. 2013. Exploring Students' Language Awareness Through Intercultural Communication in Computer-Supported Collaborative Learning. Educational Technology \& Society, 16 (2): 325-342.

Yazigi, Rana and Paul Seedhouse. 200) . Sharing Time with Young Learners", TESLEJ. Teaching English as a Second or Foreign Language (9) 3, 2005: 1-26.

Yufrizal, Herry. 2007. Negotation of Meaning by Indonesia Efl Learners. Bandung: Pustaka Reka Cipta. 